\title{
The Skateboard Factory: a teaching case on discrete-event simulation
}

\author{
Marco Aurélio de Mesquita ${ }^{\mathrm{a} *}$, Fernanda Barreto de Almeida Rocha Mariz ${ }^{\mathrm{a}, \mathrm{b}}$, João Vitor Tomotani ${ }^{\mathrm{a}}$ \\ aUniversidade de São Paulo, São Paulo, SP, Brazil \\ blnstituto Federal de Educação, Ciência e Tecnologia do Rio Grande do Norte, São Gonçalo do Amarante, RN, Brazil \\ *marco.mesquita@poli.usp.br
}

\begin{abstract}
Real-life applications during the teaching process are a desirable practice in simulation education. However, access to real cases imposes some difficulty in implement such practice, especially when the classes are large. This paper presents a teaching case for a computer simulation course in a production engineering undergraduate program. The motivation for the teaching case was to provide students with a realistic manufacturing case to stimulate the learning of simulation concepts and methods in the context of industrial engineering. The case considers a virtual factory of skateboards, which operations include parts manufacturing, final assembly and storage of raw materials, work-in-process and finished products. Students should model and simulate the factory, under push and pull production strategies, using any simulation software available in the laboratory. The teaching case, applied in the last two years, contributed to motivate and consolidate the students' learning of discrete-event simulation. It proved to be a feasible alternative to the previous practice of letting students freely choose a case for their final project, while keeping the essence of project-based learning approach.
\end{abstract}

Keywords

Project-Based Learning. Discrete-Event Simulation. Engineering Education.

How to cite this article: Mesquita, M. A., Mariz, F. B. A. R., \& Tomotani, J. V. The Skateboard Factory: a teaching case on discrete-event simulation. Production, v27(spe), e20162262, 2017. http://dx.doi.org/10.1590/0103-6513.226216

\section{Introduction}

Teaching Discrete-Event Simulation (DES) presents a number of challenges, such as balancing hands-on and theoretical concepts and helping students to develop skills in the modelling and analyses of complex systems (Altiok et al., 2001; Greenwood \& Beaverstock, 2011). Furthermore, educators need to deal with the limited time available in undergraduate programs to present simulation as a practical tool to solve real-world problems (Greenwood \& Beaverstock, 2011; Pereira et al., 2011).

The use of real-life problems is a desirable approach when teaching simulation concepts and methods (Greenwood \& Beaverstock, 2011; Pereira et al., 2011). Simulation projects with business cases give the opportunity for students to pass through all steps of a simulation project, such as defining and delimiting the problem, collecting data, developing, verifying and validating the model, making experiments and analyzing the results (Freimer et al., 2004).

The adoption of real manufacturing cases, on the other hand, imposes some challenges. Students may have difficulty accessing manufacturing companies and, even when they do, getting technical data for realistic modeling is not an easy task. Medium to small companies are typically more receptive, but more prone to having less structured processes, which makes data collection more difficult and time-consuming. Data gathering, in particular, is a critical activity in simulation projects, especially for novice modelers (Onggo \& Hill, 2014). A common alternative is to ask the students to simulate services such as public transportation, food, medical care and banking, accessible on college campuses. Although generally easier to achieve, this practice is rather distant from the industrial engineering reality. 
The teaching of computer simulation in the production engineering context should contribute to the achievement of desired future professional skills. Eskandari et al. (2013) recently discussed these skills in the light of the opportunities and challenges for future engineers. Adaptable problem solving skills are considered the most important for engineers, followed by skills such as analytical abilities, creative and critical thinking, and teamwork capabilities (Eskandari et al., 2013).

In Engineering Education, Problem-based Learning (PBL) has been considered an alternative to improve students' performance and to achieve the desired development of technical and transversal competencies (Alves et al., 2016; Fernandes et al., 2014). In the literature, there are numerous PBL applications in different domains of Production Engineering Education, such as: Mathematics, Sciences and Programming (Alves et al., 2016); Logistics (Grasas \& Ramalhinho, 2016); Operations Management (Bamford et al., 2012; Mesquita et al., 2017; Vivas \& Allada, 2006); Lean and Six Sigma (Kanigolla et al., 2014); Product Development (Jaeger et al., 2013); and Modeling and Simulation (Pereira et al., 2011).

Active learning strategies promote student engagement in Engineering and Management Education, and PBL is a useful tool in this context. Realistic unstructured problems are used to arouse curiosity, helping students to focus on practical relevant knowledge (Fernandes et al., 2014; Prince, 2004; Smith, 2005). PBL and its variants "Case-based" and "Project-based learning" try to offer a realistic situation to prepare students to analyze real problems (Garcia et al., 2012; Prince \& Felder, 2006).

Considering all the desirable practices mentioned above, as well as the difficulty with real-life applications, we chose a different approach in our undergraduate production engineering course. To this end, we designed a simulation project of the skateboard factory, as a proposal for the final project. The teaching case was inspired in Mesquita et al. (2017), which uses a similar scenario for Production Planning and Control. Here, matters comprise the investment decision to start up a new company, and the students have to assess the production capacity as part of the business plan analysis.

The project emphasizes the application of operations research alongside with operations management concepts and methods. In this context, this paper aims to evaluate the proposed teaching case as an alternative to the conventional approach of letting students freely choose a real case to model and analyze for their final project. Therefore, the research is oriented by the following question: What contribution the virtual skateboard factory teaching case can bring to the simulation learning for industrial engineering students?

The sections below are organized as follows: Section 2 presents the theoretical background. Section 3 exposes the research materials and method. Section 4 describes the main elements of the proposed teaching case. Section 5 discusses the results and contributions, based on data collected during the application of the teaching case. Finally, Section 6 draws conclusions and indicates limitations and future work directions.

\section{Theoretical background}

Engineering education is frequently criticized for its emphasis on mathematical formulations and tools that distances the students from professional practices (Smith, 2005). Empirical studies support this criticism, showing a gap between what is taught in the classroom and reality (Abraham \& Karns, 2009; Basnet, 2000; Green et al., 1977). Felder (2006) considered outdated the traditional expository methodology of engineering courses, asserting that in traditional lectures, the professor loses its relevance and is not able to enrich the classroom experience. In view of such criticism, engineering schools have sought alternative teaching techniques to more effectively involve students in the learning process. Certainly, more involvement results in greater motivation and comprehension of course content (Prince, 2004; Tang \& Austin, 2009).

As mentioned in the Introduction, the PBL methodology and its variations have received more attention among researchers and teachers lately. It has been adopted by numerous universities as a way to reduce the gap between theory and practice (Bamford et al., 2012; Smith, 2005), since it uses the problem assessment as a starting point for the learning process and then places the responsibility on the students (Litzinger et al., 2011; Warnock \& Mohammadi-Aragh, 2016). Rather than simply allowing passive assimilation of a larger amount of information, PBL encourages students to logically structure new concepts, integrating them into their academic baggage (Capon \& Kuhn, 2004). Furthermore, PBL methodology is highly interdisciplinary, requires group work and is structured based on students' expectations, interests and experiences, all of which lead greater motivation (Graff \& Kolmos, 2003).

The possible benefits of a PBL approach are (a) the development of logical reasoning and problem-solving skills; (b) greater motivation; (c) self-directed learning; (d) improved written and oral communication skills; (e) improved teamwork skills; (f) greater professional knowledge (Sherwood, 2004; Warnock \& Mohammadi-Aragh, 2016). All these skills are highly prized in a newly graduated engineer (Eskandari et al., 
2013; Warnock \& Mohammadi-Aragh, 2016). Thus, according to market expectations, PBL is more appropriate and efficient in the training of future engineers than traditional teaching methods (Mills \& Treagust, 2003; Warnock \& Mohammadi-Aragh, 2016).

Still, the effectiveness of a PBL depends on engaging students in discussions and problem solving exercises. Therefore, some authors proposed the use of activities such as oriented projects or thematic real case-based scenarios to provide a first contact with the more practical reality of engineering (Kanigolla et al., 2014; Vivas \& Allada, 2006). This is at the heart of the problem when teaching simulation in engineering courses.

Teaching simulation presents the same challenges as teaching other disciplines of the engineering curriculum, since it involves many new concepts, resources and complexities (Giusti et al, 2008). Although widely used as a tool in different operations management disciplines, there are a limited number of papers that specifically discuss the teaching of simulation techniques themselves (Girotti \& Mesquita, 2016; Taj \& Mousavidin, 2015).

Greenwood \& Beaverstock (2011) pointed out the need for changes in how simulation is taught. These authors highlight the potential of currently available software and the need to show that simulation is a powerful tool that integrates theory, practice and problem-solving (see also Pereira et al. (2009), for an explanation of how simulation software works). Naturally, PBL and, in particular, the use of case studies, are deemed critical in teaching novice modelers (Powell \& Willemain, 2007; Saltzman \& Roeder, 2013; Sanders et al., 2016; Standridge, 2000).

A well-developed teaching case presents several advantages: (a) the assuredness that the project is feasible and related to industrial management (obtaining and working with real data is problematic, as explained in the Introduction); (b) more cooperation and healthy competition between groups of students as they attempt to solve the same case; and (c) the greater ease in assessing students' works. However, using case studies for teaching simulation has some shortcomings: (a) they do not allow the practice of data collection; (b) by being a standard project, there is less opportunity for the occurrence of different and unexpected questions; and (c) it is potentially not as motivating for the students as the use of a real case (Pereira et al., 2011).

\section{Materials and methods}

The teaching case presented here (The Skateboard Factory) was designed as a final project for a simulation course of the third year in an undergraduate Production Engineering program at the University of São Paulo, Brazil. The course syllabus includes Data Analysis, Queuing Theory, Monte Carlo Simulation, Discrete-Event Simulation, Simulation Projects, and Optimization and Simulation.

The simulation course starts with the most theoretical topics of stochastic processes and queuing theory, following a more traditional approach of lecture-based classes with classroom exercises and assignments. Later in the course, the teaching of simulation topics follows more closely the PBL approach, having the solution of the skateboard factory case as center point. Prior to the final project, simulation software tutorials are provided, presenting two main commercial packages, Arena and Simul8, and the open-source library SimPy for discrete-event simulation in Python. Each student team then decides which software to use. For a complete survey on simulation software, see Dias et al. (2016).

Since teaching cases aim to imitate real situations (Ambrosini et al., 2010; Garcia et al., 2012), it is necessary to collect data about the situation, trying to reproduce imperfections such as biased information and non-linear structures. The skateboard factory was thus designed mainly based on secondary data about products, process and resources. The case is presented in more detail in Section 4.

In order to "solve" the case, the students organized themselves into teams of four to five members. The statement of the case is given to the students prior to its introduction in class. In the following class, the professor reviews the statement, discusses the problem and answers questions. A video showing how skateboards are made is presented, so the students can have a better understanding of a skateboard factory. Students are encouraged to critically analyze the presented information and then correct and/or supplement it with their own research, if necessary.

Support is offered during the entire project. Students could interact with the professor, the assistant and other teams in lab classes and through Virtual Learning Environment forums. Each team needed to submit a written report containing the problem formulation, the simulation model, the scenarios considered, the results and analysis. In addition to the report, an oral presentation of 20 minutes summarizing their work was required. Two students were randomly chosen for this presentation. The professor and the teaching assistant, who had already evaluated the report, could ask some questions to each team after the presentation; all team members could interact and respond.

Some procedures were adopted to evaluate PBL's contribution and the main difficulties of the case application. As a first approach, an online questionnaire was applied to the undergraduates. Student feedback is considered 
a good tool to analyze the impact of the teaching methodology in the educational process, showing what can be improved and how (Kanigolla et al., 2014). Our survey consisted of twelve five-point likert-type scale questions, one multiple choice question about the final project format and a last open question for comments and suggestions.

In addition, as an action research (Case \& Light, 2011), the professor and the assistant were involved in the project execution, observing how students conducted their work. During classes, it was possible to notice the students' interactions, reactions and difficulties. This also served as a tentative indication of how engaged the students were in learning through the PBL method. Finally, the final report of each team was also used to analyze how each group coped with the interdisciplinary issues of the case, how they applied simulation concepts and methods and, ultimately, how they achieved their results.

\section{The teaching case}

\subsection{The Skateboard Factory}

The teaching case begins with an entrepreneur who is planning to start a skateboard factory, but is not sure about the feasibility of his business plan. He decides to consult experts to assess the plant capacity and the investments required for its setup. The team of students represents the experts, who must develop a simulation model to assess the capacity and the balance of the plant's resources. Additionally, they are asked to simulate the operation under push and pull production strategies.

The skateboard was chosen as the product due to its simple production, but with an adequate number of parts and processes that provides a level of complexity consistent with the objectives of the teaching case and course. In addition, it is a common product, known by all students. The skateboard factory will manufacture only decks and wheels, and buy the other components (Figure 1). In addition to the assembled skateboards, the company will sell parts and accessories.

The company is being designed to operate under make-to-stock (MTS) production strategy and the plant will produce in batches of fixed size. The batch production consists of a sequence of one or more steps that must be performed in defined order and, when the sequence is completed, a finite quantity of finished products is produced (Barker \& Rawtani, 2005). Figure 2 shows the production process.

The manufacturing of decks is divided into three stages, each taking place on a different day and with intermediate storage in between. The first stage consists in the pressing of sheets of wood to form the boards, which are then sent to the storage area. On the next day, the shaping processes (cutting, drilling, and finishing) and the painting (sealing the deck) are done, and the boards are left in the drying area until the next day. On the final day, the printing of the art at the bottom of the deck occurs and the finished decks are sent to packaging or assembly.

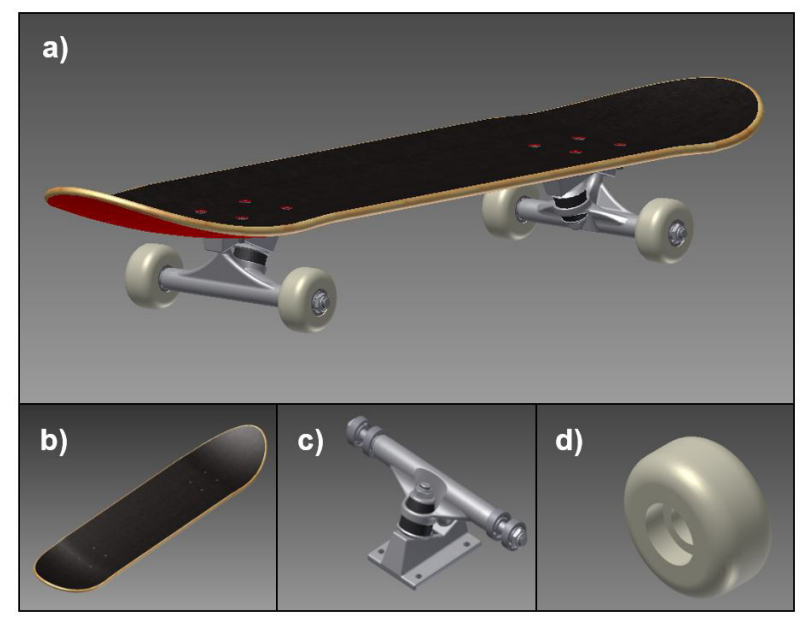

Figure 1. Skateboard parts: (a) skateboard, (b) deck, (c) truck, (d) wheel. 


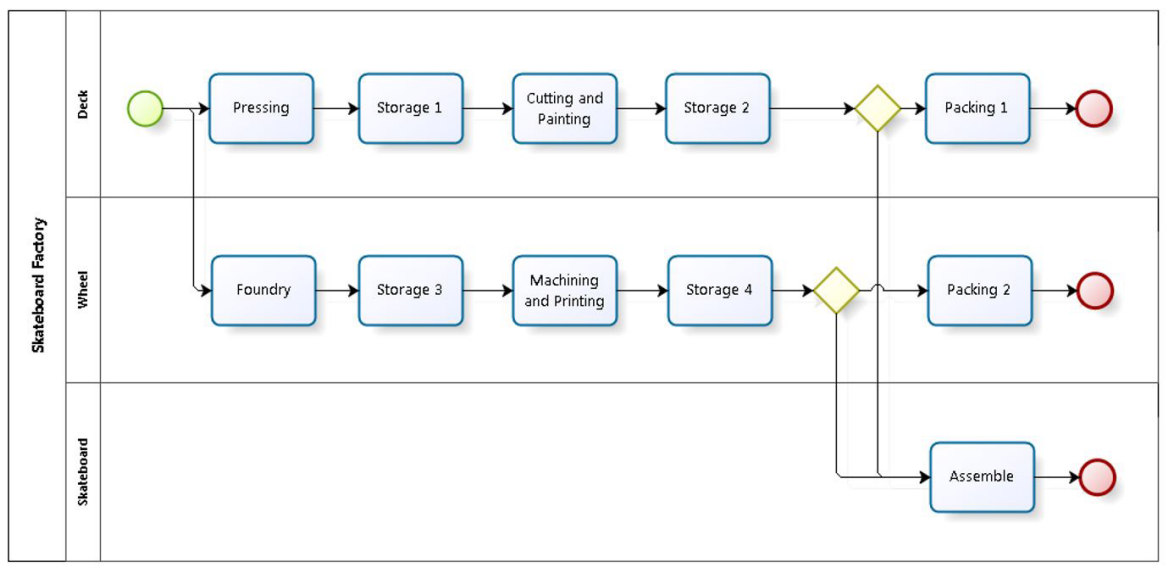

Figure 2. The production process.

Similarly, the manufacturing of wheels takes three days, with intermediate storage as well. On the first day, the casting of the wheels is made. On the second day, the machining and printing are made. Finally, on the third day the wheels are sent to packaging or assembly. The production processes described above are similar to that from Petruso (2001).

Table 1 shows the estimates of the standard times of the main processes and the corresponding critical resource. Packing the decks and the assembly and packing of skateboards are planned to occur in the same work center. The factory should operate in an eight-hour shift per day. All this information is provided by the entrepreneur in the business plan and is subjected to criticism and review by the students at their discretion. Table 2 presents the demand for a standard month of 22 days.

Table 1. Processes parameters.

\begin{tabular}{|c|c|c|c|c|c|}
\hline Process & Product & Lot Size (un.) & $\begin{array}{l}\text { Process Time } \\
\text { (min/lot) }\end{array}$ & Critical Resource & Quantity (un.) \\
\hline Pressing & Deck & 24 & 100 & Press & 4 \\
\hline Cutting & Deck & 24 & 60 & Worker & 3 \\
\hline Painting & Deck & 24 & 20 & Worker & 1 \\
\hline Finishing & Deck & 24 & 15 & Worker & 1 \\
\hline Foundry & Wheels & 192 & 55 & Furnace & 1 \\
\hline Machining & Wheels & 192 & 60 & lathe & 2 \\
\hline Printing & Wheels & 192 & 20 & Printing Machine & 1 \\
\hline Packing Decks & Box of Decks & 12 & 10 & Worker & 2 \\
\hline Packing Wheels & Set of Wheels & 48 & 30 & Packing Machine & 1 \\
\hline Assembly line & Skateboards & 24 & 30 & Worker & 2 \\
\hline
\end{tabular}

Table 2. Demand Forecast.

\begin{tabular}{cc}
\hline Product & Demand (per month) \\
\hline Skateboard & 5,280 \\
Box of Decks (8 un.) & 440 \\
Wheels package (4 un.) & 2,640 \\
\hline
\end{tabular}

\subsection{The simulation project}

The project aims to consolidate the concepts and methods of simulation modeling and analysis of manufacturing systems. As such, students should go through a variety of activities and tasks during the project.

Important issues to evaluate are work-in-process inventories, idleness of equipment, bottleneck processes, and how the factory responds to demand and production uncertainties. Some questions were directly posed to 
the students: (a) Does the production system have the capacity to meet the forecasted demand? (b) What are the bottleneck resources in the system? (c) Are the resources well balanced? (d) How to simulate the factory under a pull production strategy? (e) How can the model be used to define inventory levels and capacity of storage areas?

The students should build models and run simulations, considering first a push production and then a pull production version of the factory. As seen in Figure 2, the production comprises basically five processes: manufacturing of decks, manufacturing of wheels, packing skateboards, packing decks, and packing wheels.

Students were encouraged to build their models first with the manufacturing processes under push production and considering deterministic data. The next step is to include randomness by choosing the appropriate probability distributions and its parameters for the arrival and production processes. In the push mode, orders are generated on a daily basis and released to flow through the process.

In the manufacturing of decks, the challenge is to model the hold process of intermediate products that has to wait until the next day to continue downstream. Modeling the manufacturing of wheels is very similar. Students can simulate each model first with deterministic and then with random demand and manufacturing processes to identify the bottlenecks and line capacity.

Next, they must model the packing of skateboards, which is basically an assembly process. The model should pick one lot of decks and another of wheels to proceed with the packing process. Lots of decks and of wheels are dimensioned to match the needs for exactly one lot of skateboards.

In simulation tutorials, several ways to model the assembly process in different simulation software were presented. Then, it is possible to analyze the capacity in a more complex flow. Depending on how the process times are set, the bottleneck can be in any of the two manufacturing process, or even in the packing ("assembly") process.

To finish the push model, students must include the other two packing processes, namely, packing boxes of decks and sets of wheels. To do this, they should include a gate to route the decks and wheels to the proper downstream process. With this, the capacity balancing becomes even more complex and challenging.

Once the push model is completed, students can try to model the pull production. One way to implement it is to consider an "order up to" inventory policy that would work as follows: (a) daily demands are generated for each product; (b) demands are filled partially or totally, depending on the stock available; (c) the amount shipped (equal to the filled demand) becomes the amount to be produced.

In fact, as production is in batches, additional calculations are needed to determine orders size. Due to the rounding of orders quantities, the stock will hardly ever reach its full level. In addition, by modeling the operations' dynamics, the model can also evaluate performance measures as fill rate and average inventory levels of finished products. Figure 3 shows the representation of the pull model for the factory, including decks, wheels and skateboards.

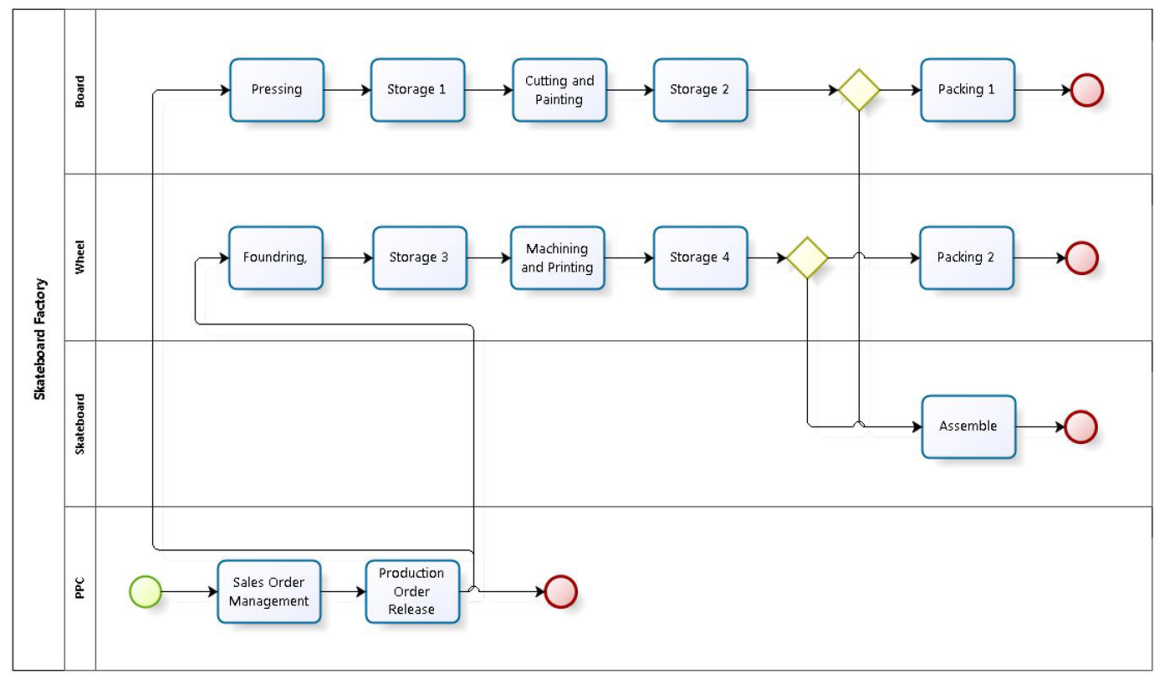

Figure 3. The pull production process. 


\section{Results and discussions}

The teaching case was applied in class during the last two years. The first application can be considered a "trial run", so the results presented herein are from the second (improved and more robust) application.

The 100 students enrolled in the course organized themselves in 20 teams, of which $85 \%$ were approved in the first evaluation. Figure 4 shows a summary report for the Final Project Grades (on a scale from zero to ten), including the single group that failed to conclude the project (grade zero).

To assess the opinion of the students regarding the teaching case, an online questionnaire was applied at the end of the course. The objective of the survey was not only to evaluate the effectiveness of the teaching case, but also to identify opportunities for improvement. The questionnaire had a total of 14 questions and was answered by 32 students. The results of questions 1 to 12 are presented on Table 3, with the average score for each shown in Figure 5. Table 4 shows the responses for question 13. The final question was an open one, answered by 10 students, and will be discussed later.

In the first question, most of the students declared that all the members of the group participated in the project. Team working was also verified in the interactions with the teacher and the teaching assistant, and in the final presentation of the groups. It should be noted that, by the way the question was asked and the fact

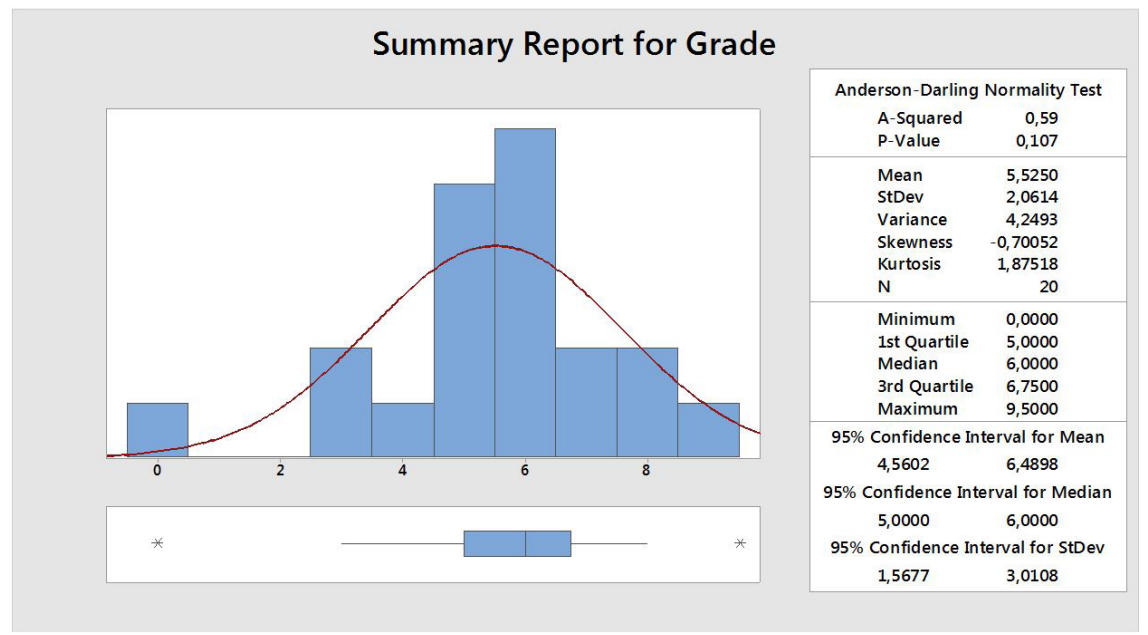

Figure 4. Summary report for Final Project Grades (Minitab ${ }^{\infty}$ 17).

Table 3. Questions 1 to 12 of the survey.

\begin{tabular}{|c|c|c|c|c|c|}
\hline & $\begin{array}{l}\text { Strongly } \\
\text { Disagree }(0)\end{array}$ & $\begin{array}{l}\text { Disagree } \\
\text { (1) }\end{array}$ & $\begin{array}{l}\text { Neutral } \\
(2)\end{array}$ & $\begin{array}{l}\text { Agree } \\
\text { (3) }\end{array}$ & $\begin{array}{c}\text { Strongly } \\
\text { Agree } \\
\text { (4) }\end{array}$ \\
\hline $\begin{array}{l}\text { 1. All the members of the group participated actively in the } \\
\text { resolution of the teaching case }\end{array}$ & 3 & 3 & 6 & 12 & 8 \\
\hline 2. My group did well in solving the teaching case & 0 & 5 & 8 & 15 & 4 \\
\hline $\begin{array}{l}\text { 3. The teaching case helped to consolidate the concepts and } \\
\text { methods of simulation }\end{array}$ & 0 & 3 & 5 & 15 & 9 \\
\hline $\begin{array}{l}\text { 4. Software tutorials were adequate as preparation for the } \\
\text { solution of the case }\end{array}$ & 4 & 6 & 13 & 9 & 0 \\
\hline $\begin{array}{l}\text { 5. The theoretical background (queuing theory and } \\
\text { simulation) were adequate }\end{array}$ & 1 & 1 & 12 & 12 & 6 \\
\hline $\begin{array}{l}\text { 6. The teaching case motivated the learning of the concepts } \\
\text { and methods of simulation }\end{array}$ & 0 & 5 & 10 & 13 & 4 \\
\hline 7. The time available to complete the case was adequate & 0 & 8 & 12 & 7 & 5 \\
\hline 8. The level of difficulty of the teaching case was adequate & 0 & 4 & 12 & 13 & 3 \\
\hline 9. The teaching case description was clear & 7 & 8 & 11 & 4 & 2 \\
\hline 10. The grade attributed to my group was fair & 3 & 5 & 5 & 9 & 10 \\
\hline 11. The software used in the teaching case was adequate & 1 & 3 & 5 & 18 & 5 \\
\hline $\begin{array}{l}\text { 12. The support offered by the teacher's assistant was } \\
\text { adequate }\end{array}$ & 1 & 5 & 14 & 9 & 3 \\
\hline
\end{tabular}




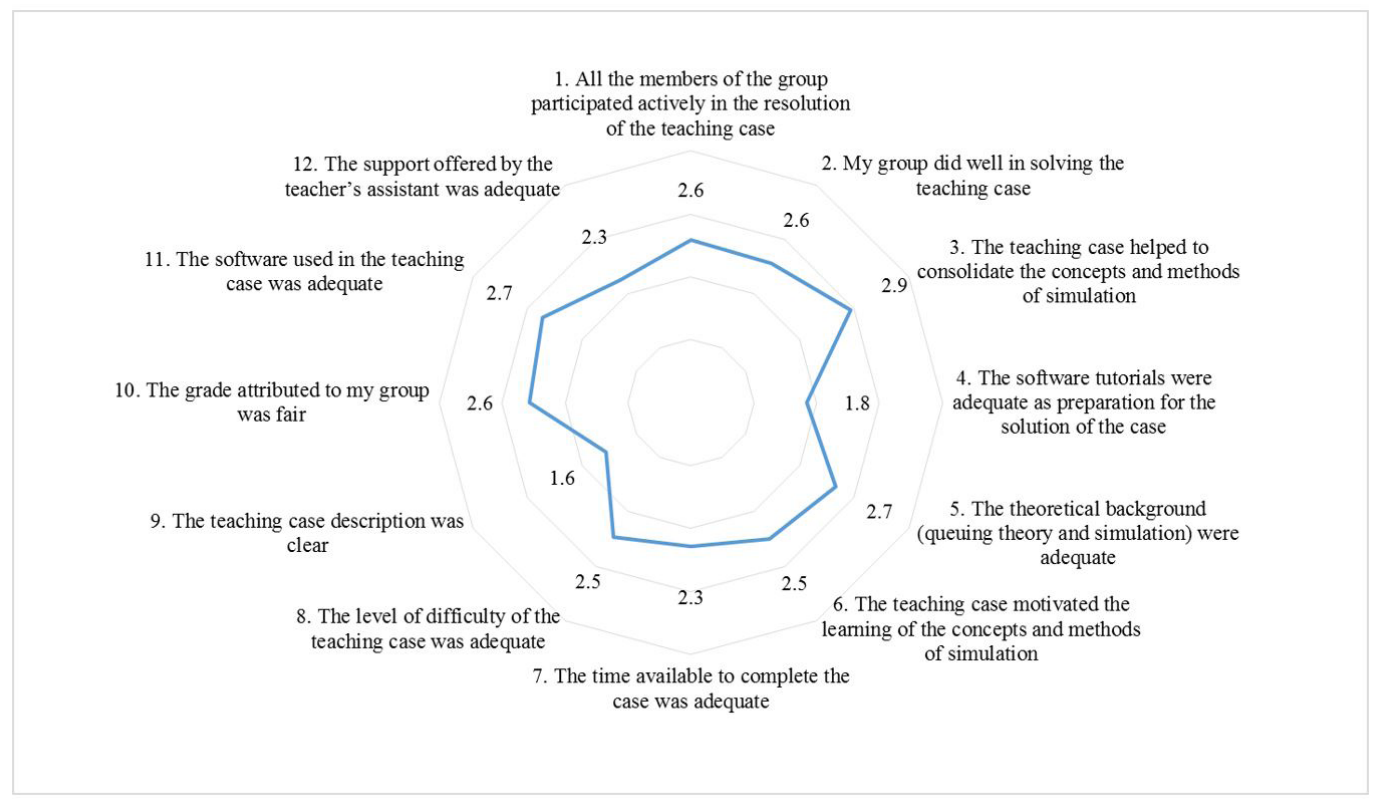

Figure 5. Radar chart of the survey results.

Table 4. Students' answers to Question 13 "Which of the following do you consider the most appropriate for the course final project?".

\begin{tabular}{lcc}
\hline Answer & Count & Percentage \\
\hline "To solve a teaching case like the one proposed in the discipline." & 27 & $84.4 \%$ \\
"Let students freely choose a real modeling case." & 4 & $12.5 \%$ \\
"1 do not think it necessary to have a practical work in the discipline." & 1 & $3.1 \%$ \\
Total & 32 & $100 \%$ \\
\hline
\end{tabular}

that the groups were relatively large, it was enough that only one of the members was less involved so that the score in this question is lower. Our perception is that there was a great involvement of the students in solving the case, which is in line with the precepts of the PBL approach (Sherwood, 2004; Warnock \& MohammadiAragh, 2016; Yadav et al., 2010); good teamwork is an important skill desired for a production engineer (Eskandari et al., 2013).

It is worth noting that in some groups, one member ended up taking a more active role in the development of the computational model. This fact may be an intrinsic feature of the nature of the simulation projects. The same behavior was noticed by the professor in previous classes, when the students worked with real cases. To encourage the participation of all students and promote the development of communication skills, the professor introduced a group presentation in the final class. During presentations, students demonstrated a good understanding of their projects.

In Question 3, most of the students agree with the importance of the teaching case to consolidate and encourage the learning of simulation, which is in line with the literature (Capon \& Kuhn, 2004; Saltzman \& Roeder, 2013; Standridge, 2000). The teaching case was designed to be closer to the reality of production engineering, resulting in a greater interest by the students. One statement in particular says: "The application of concepts through a more complex simulation in the semester was very exciting. 1 think it is very important for motivation and learning." (translated from the original in Portuguese).

The students also considered that the case motivated the learning of simulation concepts and methods (Question 6), reinforcing the benefits of this approach (Standridge, 2000). Taking into account the complexity of the project and the high workload at the end of the semester, these results are encouraging.

Nevertheless, Question 2 shows that the students' performance was only satisfactory, suggesting that they had some difficulties, as hinted by other questions. Question 10, however, shows that most of the students considered the evaluation fair, while Questions 5 and 8 points out, respectively, that the theoretical background 
and degree of difficulty of the project was adequate. Some students complained that more time was required to properly complete the case (Question 7). For the professor, such complaint is not fully justified, it just emphasizes the need for the students to better manage the time in the execution of the project. Anyway, some students suggested dividing the project in two parts: first, the capacity analysis under push strategy, and second, the model and analysis of the pull production.

In solving the case, groups could freely choose which simulation software to use (tutorials were given for Arena, Simul8 and SimPy). Question 4 shows that the tutorials were not fully satisfactory, but the professor's idea is that the tutorials were supposed to be an introduction to the software and not to cover all of their features. As such, it was expected that the students would search for more information about the chosen software as demanded by the project. Some teams, for instance, have implemented more elaborate logics than those presented in the tutorials to better model pull production. Despite this criticism, students considered the software chosen to be adequate to solve the case (Question 11).

Students' answers to Question 12 regarding the support offered by the teaching assistant, show that they were not fully satisfied with the support provided. The answers present a positive correlation with those of Question 4 on the tutorials. During the project, both professor and assistant were always available at scheduled times, although they were sparsely activated. Again, there is a dilemma between the student's preference for ready responses as opposed to research and discovery of solutions by self-effort, another principle of active learning (Prince, 2004).

One of the greatest complaints was about the case description (Question 9), with frequent doubts regarding the capacity and quantity of resources in the business plan. In preparing the case, we were careful to present the case openly, with margin for interpretation, which is consistent with the PBL approach.

Students were encouraged to seek additional information to supplement or correct any piece of information provided. It was also stressed that the data presented should be considered as starting point and that the students were "hired" as consultants exactly to evaluate the feasibility of the plan. In fact, the plan contained some over and undersized resources, and it was up to the groups to propose better balance to the factory.

Still, many students felt insecure to make assumptions for solving the case, as illustrated by the following statement:

I believe that the case description could have given more information for the development of the project. We made our model based on some assumptions that we were unsure if they could be used or not, which took a lot of discussion. This time could have been spent in a better modelling rather on the interpretation of the statement of problem (translated from Portuguese).

The statement from a student in the first application of the case is very similar:

[...] we found many difficulties in interpreting the statement of the problem, perhaps due to our lack of contact with more practical problems. There was a lot of information in the statement, and we did not know how to apply them in the project (even less discern if the information should be or not in the model). This somewhat complicated the flow of the project and, in our case, prevented us from making a good analysis. As much as the production process itself was clear, there was much interlaced information and tables that were linked to other tables, and I believe this complicated the problem. The project itself was very difficult. Maybe make it clear which information is essential to the model, or organize the information more clearly. However, 1 know that this may have been a mistake of our group in interpreting the statement (translated from Portuguese).

In a typical case study experience, the problem does not need a clear-cut or "correct" solution; the important issue is that it allows students to become flexible thinkers as they "[...] learn to filter out distracting information, furnish missing information with inferences, and associate evidence from different parts of the case and integrate it into a solution [...]" (Garcia et al., 2012, p. 451).

Simulation projects normally involve data collection and interpretation, so deciding what kind of data to collect is a central concern (Onggo \& Hill, 2014). In the teaching case approach, the students did not collect data, but had to make inferences and dig for information to build their models. This allows them to develop analytical and problem solving skills (Garcia et al., 2012).

In the open question (Question 14), the main complaints were that the project was harder than expected and that it could have been handed out earlier, at the beginning of the course. An interesting and challenging criticism was the fact that all groups worked on the same case (as seen in the following statement): "[...] if you prepared 5 or more cases and allocated them to different groups, the project would be less repetitive and the students would like it more." (translated from Portuguese).

In spite of the criticisms, the comments were generally positive, regarding both the teaching case and the interest it aroused in learning. Returning to our initial question: what the present teaching case brings to the 
students? It can be said that it achieved its goal of providing a relevant learning experience for students in Production Engineering, even being a virtual factory (and not a real factory).

The answers to Question 13 corroborate this, also point out the students' preference for the teaching case instead of a real case. Previous experience has shown that students find it difficult to reach out companies and acquiring their technical data, which leads to frustration and distancing from the industrial environment. In this way, the teaching case is an interesting alternative, especially when referring to an introductory course on simulation and for large classes.

\section{Conclusion}

In the present paper, we proposed a teaching case and analyzed its effectiveness when applied in a third-year simulation course for undergraduate Production Engineering students. The case exposed students to open situations, where they could apply the knowledge acquired during the course and develop problem-solving and decision-making skills.

The teaching case was able to address a complex modeling problem, feasible with the available software. The proposed project tackled push and pull production strategies, as well as the modeling of manufacturing and assembly operations, all of which are important concepts for industrial engineers.

The presentation of the case as a business plan challenged students to deal with incomplete information, a common situation in professional activity. A limitation observed is the need for renewal of the case because, from one class to another, the challenge becomes less relevant. One possibility is to adapt the skateboard factory project by replacing the product with any other products and processes with similar complexity.

Finally, it can be safely said that a case based on a virtual factory is an interesting alternative to real-life scenarios. The case will be applied again in the present year, with the required improvements discussed above, and has also been adapted to two other teaching cases (in the courses of Cost Management and Production Planning and Control).

\section{References}

Abraham, S. E., \& Karns, L. A. (2009). Do business schools value the competencies that businesses value? Journal of Education for Business, 84(6), 350-356. http://dx.doi.org/10.3200/J0EB.84.6.350-356.

Altiok, T., L’Ecuyer, P., Schmeiser, B. W., Schruben, L. W., Kelton, W. D., \& Nelson, B. L., \& Wilson, J. R. (2001). Various ways academics teach Simulation: are they all appropriate? In B. A. Peters, J. S. Smith, D. J. Medeiros, \& M. W. Rohrer (Eds.), Proceedings of the 2001 Winter Simulation Conference. Arlington, VA, USA. http://dx.doi.org/10.1109/WSC.2001.977367.

Alves, A. C., Sousa, R. M., Fernandes, S., Cardoso, E., Carvalho, M. A., Figueiredo, J., \& Pereira, R. M. S. (2016). Teacher's experiences in PBL: implications for practice. European Journal of Engineering Education, 41(2), 123-141. http://dx.doi.org/10.1080/03043 797.2015.1023782.

Ambrosini, V., Bowman, C., \& Collier, N. (2010). Using teaching case studies for management research. Strategic Organization, 8(3), 206-229. http://dx.doi.org/10.1177/1476127010374254.

Bamford, D., Karjalainen, K., \& Jenavs, E. (2012). An evaluation of problem-based assessment in teaching operations management. International Journal of Operations \& Production Management, 32(12), 1493-1514. http://dx.doi.org/10.1108/01443571211284214.

Barker, M., \& Rawtani, J. (2005). Practical bathc process management. Amsterdam: Elsevier.

Basnet, C. (2000). Production management in New Zealand: is education relevant to practice? International Journal of Operations \& Production Management, 20(6), 730-745. http://dx.doi.org/10.1108/01443570010321694.

Capon, N., \& Kuhn, D. (2004). What's so good about problem-based learning? Cognition and Instruction, 22(1), 61-79. http://dx.doi. org/10.1207/s1532690Xci2201_3.

Case, J. M., \& Light, G. (2011). Emerging methodologies in engineering education research. Journal of Engineering Education, 100(1), 186-210. http://dx.doi.org/10.1002/j.2168-9830.2011.tb00008.x.

Dias, L. M. S., Vieira, A. A. C., Pereira, G. A. B., \& Oliveira, J. A. (2016). Discrete simulation software ranking - a top list of the worldwide most popular and used tools. In T. M. K. Roeder, P. I. Frazier, R. Szechtman, E. Zhou, T. Huschka, \& S. E. Chick (Eds.), Proceedings of the 2016 Winter Simulation Conference, Arlington, VA, USA.

Eskandari, H., Sala-Diakanda, S., Furterer, S., Rabelo, L., Crumpton-Young, L., \& Williams, K. (2013). Enhancing the undergraduate industrial engineering curriculum. Education + Training, 49(1), 45-55. http://dx.doi.org/10.1108/00400910710729875.

Felder, R. M. (2006). Teaching engineering in the 21st century with a 12th century teaching model: how bright is that? Chemical Engineering Education, 40(2), 110-113.

Fernandes, S., Mesquita, D., Flores, M. A., \& Lima, R. M. (2014). Engaging students in learning: findings from a study of project-led education. European Journal of Engineering Education, 39(1), 55-67. http://dx.doi.org/10.1080/03043797.2013.833170.

Freimer, M., Roeder, T. M., Schruben, L. W., Standridge, C. R., Harmonosky, C. M., \& Ståhl, 1. (2004). You are going to teach Simulation - now what? Tips and strategies. In R. G. Ingalls, M. D. Rossetti, J. S. Smith, \& B. A. Peters (Eds.), Proceedings of the 2004 Winter Simulation Conference, Washington, DC, USA. 
Garcia, J., Sinfield, J., Yadav, A., \& Adams, R. (2012). Learning through entrepreneurially oriented case-based instruction. International Journal of Engineering Education, 28(2), 448-457.

Girotti, L. J., \& Mesquita, M. A. (2016). Simulação e estudos de caso no ensino de planejamento e controle da produção: um survey com professores da engenharia de produção. Production, 26(1), 176-189. https://doi.org/10.1590/0103-6513.145013.

Giusti, M. R., Lira, A. J., \& Villarreal, G. L. (2008). Simulation framework for teaching in modeling and simulation areas. European Journal of Engineering Education, 33(5-6), 587-596. http://dx.doi.org/10.1080/03043790802568138.

Graff, E., \& Kolmos, A. (2003). Characteristics of problem-based learning. International Journal of Engineering Education, 19(5), 657-662.

Grasas, A., \& Ramalhinho, H. (2016). Teaching distribution planning: a problem-based learning approach. International Journal of Logistics Management, 27(2), 377-394. http://dx.doi.org/10.1108/1JLM-05-2014-0075.

Green, T. B., Newsom, W. B., \& Jones, S. R. (1977). A survey of the application of quantitative techniques to production/operations management in large corporations. Academy of Management Journal, 20(4), 669-676. http://dx.doi.org/10.2307/255365.

Greenwood, A., \& Beaverstock, M. (2011). Simulation education - seven reasons for change. In S. Jain, R. R. Creasey, J. Himmelspach, K. P. White, \& M. Fu (Eds.), Proceedings of the 2011 Winter Simulation Conference. Phoenix, AZ, USA. https://doi.org/10.1109/ WSC.2011.6147736.

Jaeger, A., Mayhofer, W., Kuhlang, P., Matyas, K., \& Sihn, W. (2013). Total immersion: hands and heads-on training in a learning factory for comprehensive industrial engineering education. International Journal of Engineering Education, 29(1), 23-32.

Kanigolla, D., Cudney, E. A., Corns, S. M., \& Samaranayake, V. A. (2014). Enhancing engineering education using project-based learning for Lean and Six Sigma. International Journal of Lean Six Sigma, 5(1), 45-61. http://dx.doi.org/10.1108/1JLSS-02-2013-0008.

Litzinger, T. A., Lattuca, L. R., Hadgraft, R. G., \& Newstetter, W. C. (2011). Engineering education and the development of expertise. Journal of Engineering Education, 100(1), 123-150. http://dx.doi.org/10.1002/j.2168-9830.2011.tb00006.x.

Mesquita, M. A., Girotti, L. J., \& Tomotani, J. V. (2017). The skateboard manufacturing company: a teaching case on production planning and control. In M. Amorim, C. Ferreira, M. Vieira Junior, \& C. Prado (Eds.), Engineering systems and networks: the way ahead for industrial engineering and operations management (pp. 365-373). Cham: Springer. https://doi.org/10.1007/978-3-319-45748-2_39.

Mills, J. E., \& Treagust, D. F. (2003). Engineering education-ls problem-based or project-based learning the answer? Australasian Journal of Engineering Education, 3(2), 2-16.

Onggo, B. S. S., \& Hill, J. (2014). Data identification and data collection methods in simulation: a case study at ORH Ltd. Journal of Simulation, 8(3), 195-205. http://dx.doi.org/10.1057/jos.2013.28.

Pereira, D. C., Vilas, D. del R., Monteil, N. R., Prado, R. R., \& Rodriguez, A. L. (2011). A project-based teaching experience for simulation and optimization education. In Proceedings of the 7th International Conference on Next Generation Web Services Practices. Salamanca, Spain. https://doi.org/10.1109/NWeSP.2011.6088219.

Pereira, G. A. B., Dias, L. M. S., \& Rocha, H. T. C. (2009). Teaching simulation basics through flowchart simulation - the event scheduling world view. In 0. Balci, l. Castilla, F. Longo, \& M. Massei (Eds.), International Workshop on Modeling and Applied Simulation. Puerto de la Cruz, Spain.

Petruso, A. (2001). How skateboard is made - material, manufacture, making, history, used, parts, components, dimensions, steps. Retrieved in 14 February 2017, from http://www.madehow.com/Volume-6/Skateboard.html

Powell, S. G., \& Willemain, T. R. (2007). How novices formulate models. Part 1: qualitative insights and implications for teaching. The Journal of the Operational Research Society, 58(8), 983-995. http://dx.doi.org/10.1057/palgrave.jors.2602275.

Prince, M. (2004). Does active learning work? A review of the research. Journal of Engineering Education, 93(3), 223-232. http:// dx.doi.org/10.1002/j.2168-9830.2004.tb00809.x.

Prince, M. J., \& Felder, R. M. (2006). Inductive teaching and learning methods: definitions, comparisons, and research bases. Journal of Engineering Education, 95(2), 123-138. http://dx.doi.org/10.1002/j.2168-9830.2006.tb00884.x.

Saltzman, R., \& Roeder, T. M. (2013). Perspectives on teaching simulation in a college of business. In Proceedings of the 2013 Winter Simulation Conference, Washington, DC, USA.

Sanders, B., Shuttleworth, D., Deuro, J., \& Padilla, J. J. (2016). Learning discrete event simulation design methodology via interactive and collaborative projects. In Proceedings of the 49th Annual Simulation Symposium, Pasadena, CA, USA.

Sherwood, A. L. (2004). Problem-based learning in management education: a framework for designing context. Journal of Management Education, 28(5), 536-557. http://dx.doi.org/10.1177/1052562904265773.

Smith, G. F. (2005). Problem-based learning: can it improve managerial thinking? Journal of Management Education, 29(2), $357-378$. http://dx.doi.org/10.1177/1052562904269642.

Standridge, C. R. (2000). Teaching simulation using case studies. In Proceedings of the 2000 Winter Simulation Conference, Orlando, FL, USA.

Taj, S., \& Mousavidin, E. (2015). Using discrete event visual simulation to teach process modelling in MBA operations management courses. International Journal of Simulation and Process Modelling, 10(1), 45-64. http://dx.doi.org/10.1504/IJSPM.2015.068519.

Tang, T. L.-P., \& Austin, M. J. (2009). Students' perceptions of teaching technologies, application of technologies, and academic performance. Computers \& Education, 53(4), 1241-1255. http://dx.doi.org/10.1016/j.compedu.2009.06.007.

Vivas, J. F., \& Allada, V. (2006). Enhancing engineering education using thematic case-based learning. International Journal of Engineering Education, 22(2), 236-246.

Warnock, J. N., \& Mohammadi-Aragh, M. J. (2016). Case study: use of problem-based learning to develop students' technical and professional skills. European Journal of Engineering Education, 41(2), 142-153. http://dx.doi.org/10.1080/03043797.2015.1040739.

Yadav, A., Shaver, G. M., \& Meckl, P. (2010). Lessons learned: implementing the case teaching method in a mechanical engineering course. Journal of Engineering Education, 99(1), 55-69. http://dx.doi.org/10.1002/j.2168-9830.2010.tb01042.x. 